\title{
Prevalence and Quantitative Analysis of Antibiotic Resistance Genes (ARGs) in Surface and Groundwater in Meandering Part of the Kelani River Basin in Sri Lanka
}

\author{
G. Y. Liyanage $\cdot$ A. Illango $•$ \\ Pathmalal M. Manage (D)
}

Received: 19 April 2021 / Accepted: 8 August 2021 / Published online: 22 August 2021

(C) The Author(s), under exclusive licence to Springer Nature Switzerland AG 2021

\begin{abstract}
Nearly $80 \%$ of the population in the Colombo district fulfill their major requirement from the Kelani river. Recent studies are interoperating: most groundwater and surface water in Sri Lanka are contaminated with waterborne pathogens and antibiotics. In the present study, nine antibiotic resistance genes (ARGs) were screened which were belonging to two common groups of antibiotic: penicillin OPR D, bla ${ }_{T E M}$, bla ${ }_{\text {OXA }}$, amp $a$, and amp $b$ - and tetracycline - tet $A$, tet $M$, tet $B$, and tet $S$. The results of the study reveled that the surface and groundwater of the entire lower part of the Kelani river basin were contaminated with TC and FC (98\%). None of the penicillin and tetracycline group antibiotics
\end{abstract}

\section{Highlights}

- Kelani river is the second-largest watershed in Sri Lanka

- Groundwater and surface water in Sri Lanka are contaminated with waterborne pathogen and antibiotics

- Antibiotic resistance genes vs their mechanism were studied (as a first study in the country)

- Results of the study revealed that surface and groundwater are possible reservoirs of ARGs

- Results will be used to develop filters

G. Y. Liyanage $\cdot$ A. Illango $\cdot$ P. M. Manage $(\bowtie)$ Center for Water Quality and Algae Research, Department of Zoology, University of Sri Jayewardenepura, Nugegoda, Sri Lanka

e-mail: pathmalal@sjp.ac.lk

G. Y. Liyanage $\cdot$ P. M. Manage

Faculty of Graduate Studies, University of Sri

Jayewardenepura, Nugegoda, Sri Lanka were detected either surface or groundwater samples except the Kelani river mouth (amoxicillin (AMX) at $0.003 \pm 0.001 \mu \mathrm{g} / \mathrm{ml})$. The results showed that 5 to $15 \%$ of surface water samples were positive for penicillin resistance genes (bla ${ }_{T E M}$, bla ${ }_{\text {OXA }}$, OPR D, amp $a$, amp $b$ ) where $\sim 10 \%$ of groundwater samples were positive against tetracycline resistance genes (tet $A$, tet $M$, tet $S$, tet $B$ ). Among the penicillin resistance genes, the $b l a_{T E M}\left(700.576 \times 10^{2} \mathrm{copy} / \mathrm{ml}\right)$ was recorded as the highest concentration where the highest tet $A$ gene $\left(439.875 \times 10^{2}\right.$ copy $\left./ \mathrm{ml}\right)$ was detected among the tetracycline resistance genes. Therefore, water quality management and regular monitoring are essential to maintain the quality of drinking water in the meandering part of the Kelani river basin to safeguard river water consumers.

Keywords Antibiotic resistance genes (ARGs) Tetracycline $\cdot$ Penicillin $\cdot$ Water quality

\section{Introduction}

Water is an essential commodity to all life and there is not a substitute for water (Stikker, 1998). Anthropological activities, industrial discharges, sewage open outlets, hospital waste, and aquaculture effluents have been identified as major contaminants particularly in surface water in Sri Lanka (Mahagamage et al., 2016; Liyanage \& Manage, 2018). The quality of the water is the major indicator to determine human health, 
mainly in populated areas where have a high risk to receive a multitude of contaminants such as antibiotics, heavy metals, organic wastes, and xenobiotics (Qadir et al., 2008; Mahagamage \& Manage, 2015). In Sri Lanka, 29\% populations only get pipe-borne water facilities where day by day water requirement including drinking is fulfilled from groundwater, river, springs, and streams (CEA, 2017; Mahagamage \& Manage, 2019).

In Sri Lanka, there are 103 rivers starting from the central highlands and flowing through the country with increasing fertility (MOFE 2001; Mahagamage $\&$ Manage, 2018). The meandering part of the Kelani river basin acts as home to more than $20 \%$ of the Sri Lankan population and it fulfills more than $80 \%$ of drinking water requirement in Colombo district (Danish Hydraulic Institute, 1999). Compared to the other river basins, the highest urban population is recorded in the Kelani river basin (Mahagamage et al., 2020). Therefore, the pollution rate in the Kelani river is increasing as a result of poor local authority service delivery, industrial discharges, weak environmental management, and governance (CEA, 2017; Manage et al., 2020) coupled with inadequate awareness and education (Mahagamage \& Manage, 2018). Finally, it leads to an increased risk of disease transmission to people who live in the Kelani river basin (Mahagamage et al., 2020).

Greater attention has been received from national and international agencies about the antibiotic contamination of surface and groundwater along with antibiotic-resistant bacteria resulting in the development of serious pathogenic diseases in public (WHO, 2018). The use of a wide variety of antibiotics in large amounts, including non-biodegradable antibiotics in medical, aquaculture, and livestock settings, ensures that antibiotic residues remain in the aquatic environment for a long time without degradation (Russell, 2004). According to the World Health Organization (WHO), antibiotics resistant genes (ARGs) are most critical in human health challenges in the next century as ARGs serve as pathways of carrying out genetic manipulation and generate pressure for the development of antibiotic resistance in a susceptible microbial strain through horizontal gene transfer (Manage, 2018; Manage \& Liyanage, 2019; Liyanage \& Manage, 2016a).

The high adaptive capacity of microorganisms habitually associated with the spread of antibiotic resistance in the environment. Bacteria are easily susceptible to genetic changes and acquisition of mobile genetic elements which are related to antibiotic resistance (Zhang \& Li, 2011), dissolved DNA (Hernandes et al., 2013) through horizontal gene transfer (HGT) (Hernandes et al., 2013). Rapid acquisition of antibiotic resistance by pathogenic bacteria may occur via cell to cell contacts with other bacteria, which carry resistance genes on mobile genetic elements (MGEs) (Bennett, 2008; Huddleston, 2014; Manage \& Liyanage, 2019). ARGs might exist and persist in the absence of selection and challenge the dynamic equilibrium of ecosystems and enter into humans through food chains (Huddleston, 2014). Thus, the development of ARGs in the environment may create a pandemic situation in global health shortly (Hernandes et al., 2013).

Tetracycline and penicillin are widely used in livestock farming and healthcare. The major mechanisms for tetracycline resistance are prevention of drug uptake (Efflux) into the cells, ribosomal protection, and enzyme inactivation (Roberts, 2005). Efflux genes of tetracycline have been reported as tet $A$, tet $B$, tet $C$, tet $D$, tet $K$, and tet $L$ (Roberts, 2005) where the tet $M$ and tet $O$ are common genes for ribosomal protection proteins while only tet $S$, tet $X$, tet 34 , and tet 37 are coding for a protein capable of enzymatic inactivation of tetracycline (Roberts, 2005). Penicillin is one of the common antibiotics and major penicillin resistance mechanisms are antibiotic hydrolysis mediated by the bacterial enzyme beta-lactamase (bla $T E M$, bla ${ }_{\text {OXA }}$ ), changes in penicillin binding proteins (PBP) (amp a), and decreasing of porin channel formation (OPR D).

At present, European Union legislation does not include any specific regulations regarding the presence of antibiotic-resistant bacteria and ARGs in water nor their concentration thresholds. The screening of ARGs and antibiotic-resistant bacteria in the clinical and aquatic environment would therefore be the first step in tackling the rapidly growing resistance to antibiotics (Berendonk et al., 2015). The complexity of the processes and the relative scarcity of studies done, knowledge on ARGs and their role in the environment is still poorly known, and therefore, environmental studies are given priority.

ARGs and the levels, and resistance to antibioticresistant bacteria in the surface and groundwater of the meandering zone of the Kelani river basin in Sri 
Lanka are limited (Liyanage et al., 2015; Mahagamage et al., 2020). Even in Sri Lanka, tetracycline and penicillin are widely used for aquaculture and human medicine. WHO (2018) reported that antibiotic treatment for most of the waterborne diseases has created development of antibiotic resistance in pathogenic bacteria in the environment. Thus, studies are needed to find out the antibiotic resistance in the running water sources which are being used for human consumption that will help develop a strategic plan to protect surface and groundwater for the safeguard of water consumers. This is the first report on the screening and quantification of ARGs in the meandering zone of the Kelani river basin in Sri Lanka. Accordingly, in the present study, two categories of antibiotics (penicillin and tetracycline) and their resistance genes (OPR D, bla ${ }_{T E M}$, bla ${ }_{O X A}$, amp $a$, tet $A$, and tet $M$ ) were selected. The presence of these antibiotics and ARGs was identified and quantified using high-performance liquid chromatography (HPLC) and quantitative polymerase chain reaction (qPCR), respectively. Thus, the present study was aimed to evaluate the prevalence of penicillin and tetracycline resistance genes in surface and groundwater sources within the meandering zone of the Kelani river basin.

\section{Methodology}

\subsection{Sampling Sites and Sample Collection}

The Kelani river basin was physically divided into three zones: head, transition, and meandering based on the land-use practices, geology, geography, and anthropogenic activities of the river basin (Mahagamage \& Manage, 2018). In the present study, the meandering zone of Kelani river basin which starts from Awissawala to Mattakkuliya which cover three districts (Kaluthara, Gampaha, and Colombo) was selected to collect surface and groundwater samples considering the population density, industrial setting (soap, detergents, food, beverages, and pharmaceuticals), and land-use practices (home gardens, coconut, paddy, and rubber cultivation) (CEA, 2014; Mahagamage et al., 2014). Forty (40) ground

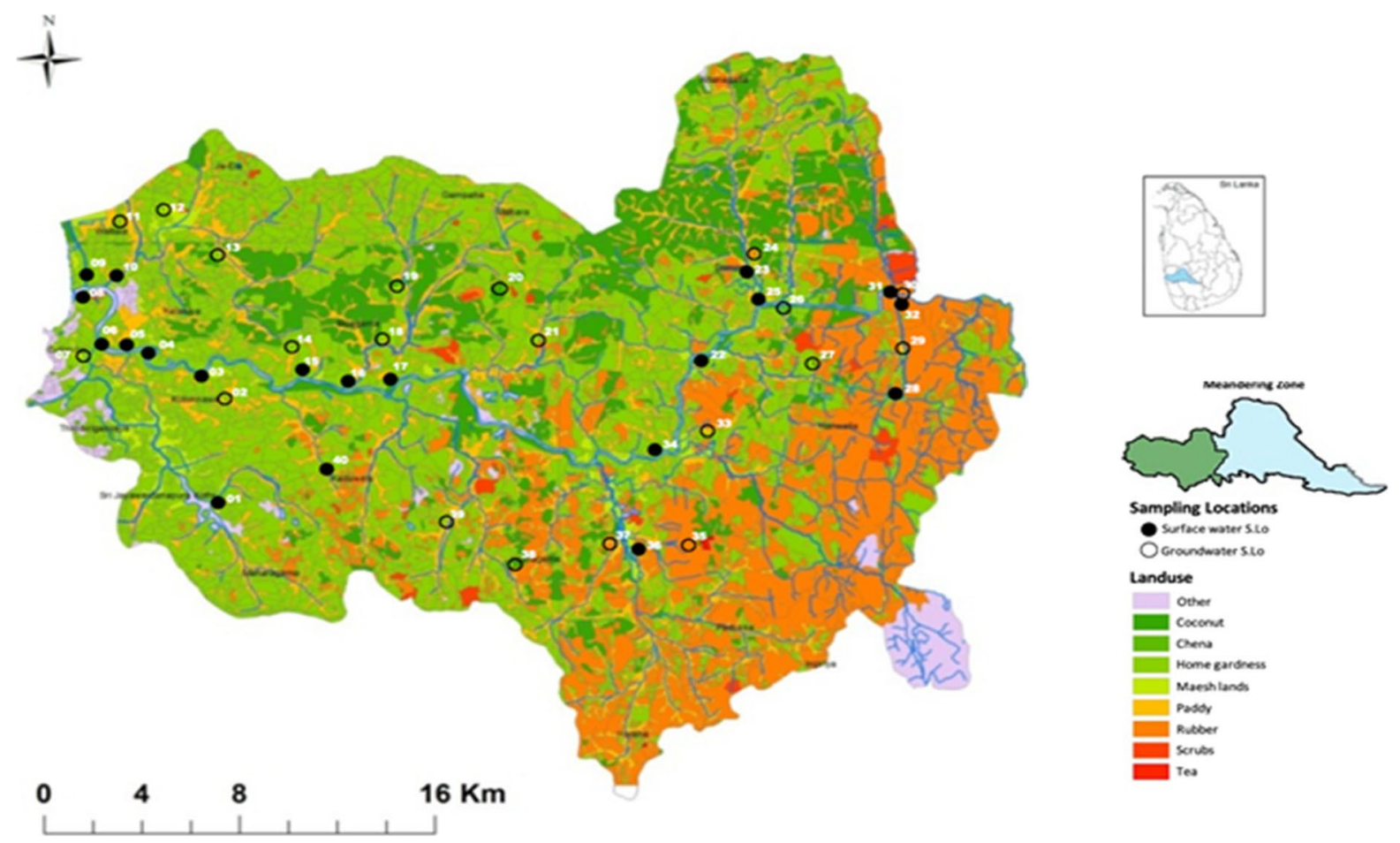

Fig. 1 Ground and surface water sampling locations with land use in the meandering zone of the Kelani river basin 
Table 1 Ground and surface water sampling locations in the meandering zone of the Kelani river basin

\begin{tabular}{|c|c|c|c|c|c|}
\hline \multicolumn{3}{|c|}{ Surface water sampling locations } & \multicolumn{3}{|c|}{ Groundwater sampling locations } \\
\hline Ref. no & Name of the location & Sample type & Ref.no & Name of the location & Sample type \\
\hline 1 & Diyawanna Oya & River water & 2 & Mulleriyawa & Well water \\
\hline 3 & Kelani river (Kohilawatte) & River water & 7 & Mattakkuliya & Well water \\
\hline 4 & Kittampahuwa canal & Canal water & 11 & Wattala & Well water \\
\hline 5 & New Keleni river bridge & River water & 12 & Enderamulla & Well water \\
\hline 6 & Sebastian canal & Canal water & 13 & Kiribathgoda & Well water \\
\hline 8 & Kelani river (Mattakkuliya) & River water & 14 & Pattiya & Well water \\
\hline 9 & Hemilton canal & Canal water & 18 & Biyagama zone & Well water \\
\hline 10 & Old Dutch canal & Canal water & 19 & Delgoda & Well water \\
\hline 15 & Kelani river (Ambathale) & River water & 20 & Dekatana & Well water \\
\hline 16 & Raggahawatta canal & Canal water & 21 & Medalanda & Well water \\
\hline 17 & Kelani river (Kaduwela) & River water & 24 & Meniklanda & Well water \\
\hline 22 & Kelani river (Giridara) & River water & 26 & Kananmpella & Well water \\
\hline 23 & Pugoda canal & Canal water & 27 & Kosgama & Well water \\
\hline 25 & Kelani river (Pugoda) & River water & 29 & Puwakpitiya & Well water \\
\hline 28 & Thummodara & Canal water & 30 & Kudagama & Well water \\
\hline 31 & Kelani river (Kudagama) & River water & 33 & Kaluaggala & Well water \\
\hline 32 & Seethawaka Zone canal & Canal water & 35 & Meepe & Well water \\
\hline 34 & Kelani river (Hanwella) & River water & 37 & Watareka & Well water \\
\hline 36 & Pusselli Oya & River water & 38 & Godagama & Well water \\
\hline 40 & Arangala & Canal water & 39 & Habarakada & Well water \\
\hline
\end{tabular}

and surface water samples were collected (Fig. 1, Table 1) in triplicate using a Rutner sampler (2L) to sterile amber color glass bottles (1L) for antibiotics and ARGs analysis following the WHO sampling protocol (WHO, 2009). Then, the collected water samples were stored in the icebox at $4{ }^{\circ} \mathrm{C}$ during transportation and kept in refrigerated condition for subsequent analysis.

\subsection{Quantification of Tetracycline and Penicillin in Water Samples}

One liter of water sample was adjusted to $\mathrm{pH} 3$ and filtered through $0.22 \mu \mathrm{m}$ Millipore filters. Filtered water samples were spiked with antibiotics at a final concentration of $100 \mathrm{mg} \mathrm{L}^{-1}$. Sep-Pak Plus C18 cartridge was used to concentrate the antibiotics after conditioning with $100 \%$ methanol and following $5 \mathrm{ml}$ deionized water (Liyanage et al., 2015). Prepared samples were passed through the $\mathrm{C} 18$ cartridges set up which was held with the SPE unit with maintaining approximately $1-2 \mathrm{ml} / \mathrm{ml}$. The $100 \%$ methanol (mobile phase) is used for eluting analytes from cartridges (Liyanage and Manage, 2014; Liyanage and Manage, 2016b). The target antibiotics were quantified by using Agilent 1200 series HPLC equipped with a diode array fluorescence detector (Fernandez-Torres et al., 2010; Liyanage and Manage, 2016a).

\subsection{Extraction of Environmental DNA from Surface and Groundwater Samples}

For DNA extraction, $250 \mathrm{ml}$ of water sample was collected and filtered through a $47 \mathrm{~mm}$ polycarbonate filter $(0.22 \mu \mathrm{m}$ pore size, Millipore). Each filter paper was soaked in $10 \mathrm{ml}$ of $70 \%$ methanol and stored at $-20{ }^{\circ} \mathrm{C}$ until use. Extraction of DNA from the filter paper was carried out according to the modified method described by Kim et al. (2012) and purification of DNA was subjected for PCR analysis.

\subsection{Detection of ARGs by PCR}

PCRs were performed to detect antibiotic resistance genes and the PCR mixtures contained $0.5 \mu \mathrm{l}$ of target primer $(10 \mu \mathrm{m}), 5 \mu \mathrm{l}$ Go taq reaction buffer, $0.5 \mu \mathrm{l}$ 
Table 2 Primers, primer sequences, and annealing temperatures used to amplify selected resistant genes of the two antibiotics employed in the present study

\begin{tabular}{|c|c|c|c|c|}
\hline Antibiotic group & Resistance gene & Primer pair & Nucleotide sequence $5^{\prime}-3^{\prime}$ & $\begin{array}{l}\text { Annealing } \\
\text { temperature } \\
\left({ }^{\circ} \mathrm{C}\right)\end{array}$ \\
\hline \multirow[t]{4}{*}{ Tetracycline } & \multirow[t]{2}{*}{ tet $(A)$} & tet A-F & 5'-GCGCGATCTGGTTCACTCG-3' & \multirow[t]{2}{*}{56} \\
\hline & & tet $\mathrm{A}-\mathrm{R}$ & 5'-AGTCGACAGYRGCGCCGGC-3' & \\
\hline & \multirow[t]{2}{*}{$\operatorname{tet}(M)$} & tet $\mathrm{M}-\mathrm{F}$ & 5'-GTTAAATAGTGTTCTTGGAG-3' & \multirow[t]{2}{*}{48} \\
\hline & & tet $\mathrm{M}-\mathrm{R}$ & 5'-CTAAGATATGGCTCTAACAA-3' & \\
\hline \multirow[t]{8}{*}{ Penicillin } & \multirow[t]{2}{*}{$O P R(D)$} & $O P R-\mathrm{F}$ & 5'-TTGGTTAGGGGCAAGTTTTG-3' & \multirow[t]{2}{*}{64} \\
\hline & & $O P R-\mathrm{R}$ & 5'-GTAATGGGCCAATAACACCG-3 & \\
\hline & \multirow[t]{2}{*}{ bla $_{T E M-1}$} & TEM-1-F & 5'-CATAGACAAGCCGTTGACC-3' & \multirow[t]{2}{*}{57} \\
\hline & & TEM-1-R & 5'-ATGTTTTTGGAACGACAGAG-3' & \\
\hline & \multirow[t]{2}{*}{ bla } & OXA-F & 5'-GCGTGGTTAAGGATGAACAC-3' & \multirow[t]{2}{*}{55} \\
\hline & & OXA-R & 5'-CATCAAGTTCAACCCAACCG-3' & \\
\hline & \multirow[t]{2}{*}{ amp a } & amp a-F & 5'-CATAGACAAGCCGTTGACC-3' & \multirow[t]{2}{*}{32} \\
\hline & & amp a-R & 5'-ATGTTTTTGGAACGACAGAG-3' & \\
\hline
\end{tabular}

dNTPs, $2.0 \mu \mathrm{l}$ from $25 \mathrm{mM} \mathrm{MgCl}$, and $0.1 \mu \mathrm{l}$ of Gotaq DNA polymerase, adjusted to a total volume of $25 \mu$ l. Purified DNA $(5 \mu \mathrm{l})$ was used as the PCR template. Optimized conditions used for the primers were shown in Table 2. PCR amplification (initial denaturation at $95{ }^{\circ} \mathrm{C}$ for $2 \mathrm{~min}$, denaturation at $95^{\circ} \mathrm{C}$ for $30 \mathrm{~s}$, annealing for $30 \mathrm{~s}$, and extension at $72{ }^{\circ} \mathrm{C}$ for $1 \mathrm{~min} / 35$ cycles) was performed using the BIOLAB PCR system thermal cycler (BYQ6078E-757, China). The final extension was performed at $72{ }^{\circ} \mathrm{C}$ for $5 \mathrm{~min}$. The amplified product was analyzed using electrophoresis.

\subsection{Quantification of Antibiotic Resistance Genes}

Quantitative PCR (qPCR) assays were employed to quantify five ARGs: bla ${ }_{T E M}$, bla ${ }_{\text {OXA }}$, amp a, tet $A$, and tet $M$, which give resistance to the penicillin and tetracycline. qPCR assays were performed using the SYBR Green (Applied Biosystems) using an Applied Biosystem 7500 real-time machine (Marti et al., 2013). Each gene was amplified using a specific primer set (Table 2) and the PCR conditions were optimized as initial denaturation at $95{ }^{\circ} \mathrm{C}$ for $3 \mathrm{~min}$, followed by 40 cycles at $95{ }^{\circ} \mathrm{C}$ for $15 \mathrm{~s}$ and the annealing temperatures are given in Table 2 for the 20 s. A dissociation curve was constructed by increasing temperature from 65 to $95{ }^{\circ} \mathrm{C}$ to confirm the specificity of the amplified products.

\subsection{Development of Standard Curves}

Standard curves were generated by cloning the amplicon from positive controls into the PBR322 vector (Invitrogen, USA). The corresponding copy number was calculated using the following equation.

Copy number $\mu 1^{-1}=\left(A \times 6.022 \times 10^{23}\right)(660 \times B)^{-1}$. where $A$ is the plasmid DNA concentration (g $\mu \mathrm{l}^{-1}$ ), $B$ is the plasmid length (bp) containing the cloned sequence, $6.022 \times 10^{23}$ is the Avogadro's number, and 660 is the average molecular weight of one base pair (Perini et al., 2011).

\subsection{Water Quality Analysis}

Water temperature, $\mathrm{pH}$, and dissolved oxygen (DO) were measured using a portable multimeter (HACH-HQ 40D), and electrical conductivity (EC), total dissolved solids (TDS), and salinity were recorded using a portable conductivity meter (HACH-Sension EC5) at the site itself. Nitrates (as $\mathrm{N}-\mathrm{NO}_{3}{ }^{-}$), nitrite (as $\mathrm{N}-\mathrm{NO}_{2}{ }^{-}$), and total phosphate (TP) concentrations were measured by the Spectrophotometric (Spectro UV-VIS Double UVD 2960) methods (APHA 1999). Membrane Lactose Glucuronide Agar (MLGA) membrane filtration method was performed to determine the total coliform (TC) and E. coli count per $0.1 \mathrm{dm}^{3}$ of the water samples (SLSI 2013). 


\subsection{Statistical Analysis}

Comparison between average antibiotic concentration and ARGs concentrations among different sampling points were carried out using one-way ANOVA test. Differences were considered significant at $p<0.05$. All statistical analysis was performed using Minitab 17 software. Pearson correlation tests were carried out for 10 physico-chemical and microbiological parameters for 40 sampling locations.

\section{Results}

\subsection{Antibiotic Concentrations}

In the present study, none of the penicillin and tetracycline group which targeted was detected at any sampling location except Kelani river mouth. However, the results of the study showed that the river mouth was contaminated with amoxicillin (AMX) in the penicillin group $(0.003 \pm 0.001 \mu \mathrm{g} / \mathrm{ml})$.

\subsection{Screening of Antibiotic Resistance Genes}

Percentage of sampling sites from 5 to $15 \%$ were positive for penicillin resistance genes (bla ${ }_{T E M}$, bla OXA, OPR D, amp a, amp $b$ ) compare to the positive sampling sites percentage $(\sim 10 \%)$ against tetracycline resistance genes (tet $A$, tet $M$, tet $S$, tet $B$ ) in groundwater samples (Fig. 2). In groundwater samples, the highest number of positive sampling sites was recorded against bla TEM $(15 \%)$, followed by descending order for bla ${ }_{\text {OXA }}(10 \%)$, tet $M(10 \%)$, amp a $(5 \%)$, and $a m p \quad b(5 \%)$, respectively (Fig. 2a). However, none of the groundwater sampling locations were positive for penicillin, $O P R D$, and tetracycline, tet $A$, tet $B$, and tet $S$.

Similarly, resistance genes of tet $A$ and tet $M$, belonging to the group tetracycline (OTC and TET),
Fig. 2 Percentages of the a penicillin (bla ${ }_{T E M}$, bla OXA $_{\text {, }}$ OPR D, amp a, amp b) and b tetracycline (tet $M$, tet $S$, tet $A$, tet $B$ ) resistance gene in surface and groundwater sampling locations in the Kelani river basin
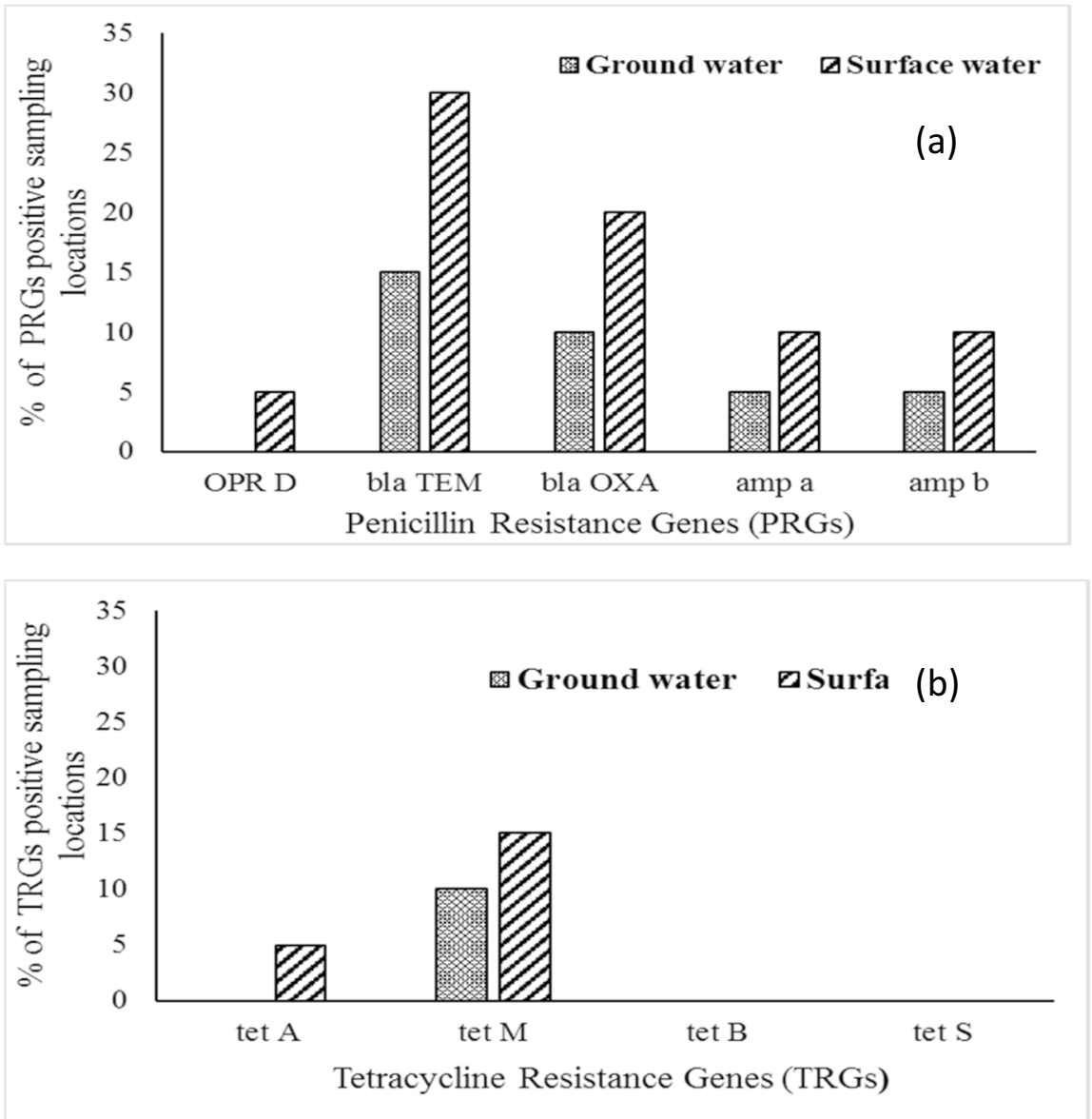
were detected as 5\% and 15\% sampling locations where penicillin resistance genes of bla ${ }_{\text {TEM }}(30 \%)$,

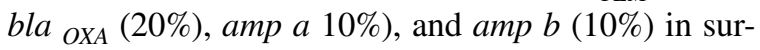
face water sampling locations, respectively (Fig. 2a and $b$ ). However, according to results of the present study tet $B$ and tet $S$ were not detected in any sampling location in the present study (Fig. 2b).

\subsection{Quantification of Antibiotic Resistance Genes}

Out of 5 genes that were initially studied during the pre-screening process of ground and surface water samples, 3 genes were selected from each resistance mechanism (changes in penicillin-binding protein, secretion of B-lactamases, and decreasing of porin channel formation) based on the gene abundance in water samples. Two genes from 4 tetracycline resistance genes were selected for further analysis based on detection frequency and response mechanism. Subsequently, these selected genes were quantified using qPCR assays. All qPCR assays showed high $R^{2}$ values $(>0.99)$ and high efficiencies from 96.84 to $107.71 \%$.

The highest ARGs ranged from $1.572 \times 10^{2}$ to $700.576 \times 10^{2} \mathrm{copy} / \mathrm{ml}$ for penicillin was recorded in surface water samples, where from $0.372 \times 10^{2}$ to $312.700 \times 10^{2} \mathrm{copy} / \mathrm{ml}$ were detected in groundwater samples (Fig. 3a). Among the penicillin resistance genes, the $b l a_{T E M}\left(700.576 \times 10^{2} \mathrm{copy} / \mathrm{ml}\right)$ was recorded as the highest concentration where the $a m p$ $a$ was ranged from $0.372 \times 10^{2}$ to $371.67 \times 10^{2}$ copy/ ml. $O P R D$ gene was recorded as $1.572 \times 10^{2}$ copy/ $\mathrm{ml}$ (Fig. 3a).
Fig. 3 a Variations of total copy numbers of antibiotic resistance genes against ß-lactam resistance genes. b Variations of total copy numbers of antibiotic resistance genes against tetracycline resistance genes; when error bars are not shown, the standard deviation was less than the width of the symbol.
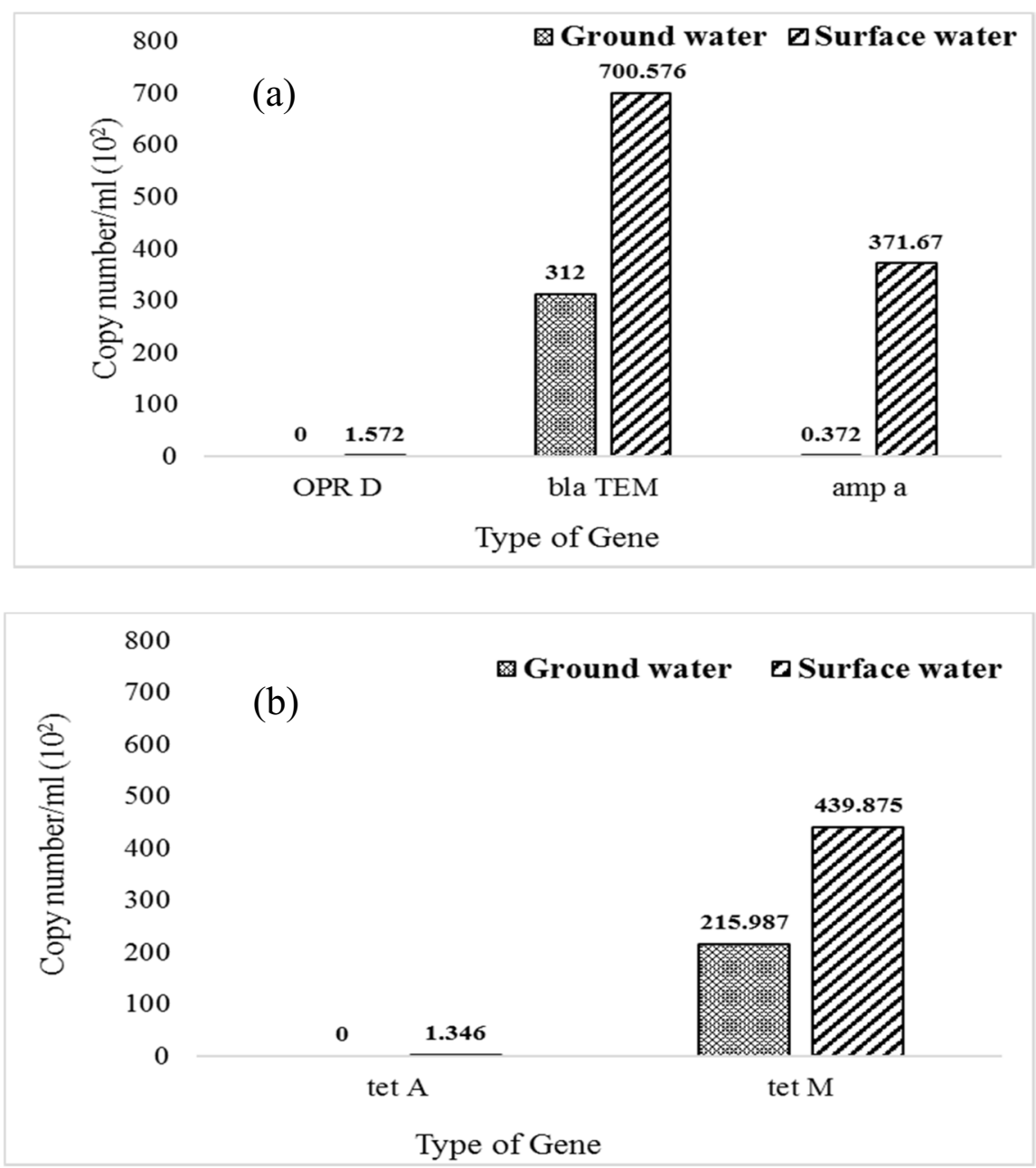
However, among the tetracycline-resistant genes, both tet $M$ and tet $A$ genes were detected in surface water samples ranging from $1.346 \times 10^{2}$ to $439.875 \times 10^{2}$ copy $/ \mathrm{ml}$, and only tet $M$ was recorded as $215.987 \times 10^{2}$ copy $/ \mathrm{ml}$ in groundwater (Fig. 3b).

\subsection{Surface and Groundwater Quality}

The surface water $\mathrm{pH}$ varied between 5.72 and 7.92 and the lowest $\mathrm{pH}$ was recorded from the Kaduwela sampling location where the EC was ranged between 52 and $2330 \mu \mathrm{S} / \mathrm{cm}$ and the highest EC value was recorded in the Hemilton canal. N-nitrate, $\mathrm{N}$-nitrite, and TP concentration were ranged between 1.21 to $11.08 \mathrm{mg} / \mathrm{L}, 1.03$ to $27.66 \mu \mathrm{g} / \mathrm{L}$, and 55.0 to $191.4 \mu \mathrm{g} / \mathrm{L}$, respectively. The groundwater $\mathrm{pH}$ varied between 4.21 and 7.30 and the lowest was recorded in the Dekatana sampling location. The EC of groundwater was ranged between 79.4 and $610.7 \mu \mathrm{S} / \mathrm{cm}$ and the highest EC was recorded in the Habarakada sampling point. N-nitrate, N-nitrite, and TP concentrations were ranged between 0.25 to $11.67 \mathrm{mg} / \mathrm{L},<1.00$ to $29.33 \mu \mathrm{g} / \mathrm{L}$, and 44.0 to $237.6 \mu \mathrm{g} / \mathrm{L}$, respectively. Further, it was found that the entire lower part of the Kelani river basin (surface and groundwater) contaminated with TC and FC (98\%). Pearson correlation showed a positive low correlation in temperature, TP, and FC; $\mathrm{pH}$ and FC; DO and nitrate where a negative low correlation was found in EC and DO.

\section{Discussion}

At present, greater attention has been paid to the heavy use of antibiotics in hospitals and the aquaculture industry by national and international health agencies due to the development of antibiotic resistance (Aminov and Mackie, 2007; WHO, 2018). The U.S. Centers for Disease Control and Prevention (CDC) has estimated due to antibiotic resistance approximately 23,000 deaths occur annually in the USA and estimated that the direct cost for treatment is about $\$ 20$ billion (CDC, 2013). However, the value for economic losses in developing countries has not been calculated so far due to a lack of published information (Laxminarayan et al., 2013).

In Sri Lanka, B-lactams and tetracycline are the most intensively used antibiotic classes for human therapies according to 2015, annual report of the
Ministry of Health, Sri Lanka (Ministry of Health, 2015). However, the same antibiotics which are used for human infections are being prescribed for different diseases of farm animals and as growth hormone in the aquaculture industry (NAQDA, 2015). In Sri Lanka, information regarding antibiotic production and usage patterns makes nervous due to limited published data.

Liyanage and Manage (2016a) have reported contaminations of amoxicillin (water: $0.001-0.023 \mathrm{ppm}$, sediment: $0.001-0.005 \mathrm{ppm}$ ), tetracycline (water: 0-0.001 ppm, sediments: not detected), sulfardiaoxine (SDI) (water: 0.001-0.003 ppm, sediments: 0.001-0.003 ppm), sulfarmethaxasol (SMX) (water: 0.001-0.018 ppm, sediments: 0.001-0.002 ppm), and erythromycin (ERM) (water: 0.001-0.008 ppm, sediments: 0.001-0.003 ppm) in hospital effluent water in Sri Lanka. Further, Liyanage et al. (2015) documented that the concentration of TET in aquaculture farms was ranged between $0.001 \pm 0.011$ and $0.112 \pm 0.017 \mathrm{ppm}$ whereas OTC ranged from $0.008 \pm 0.012$ to $0.234 \pm 0.014 \mathrm{ppm}$.

Many researchers have reported the presences of the potential of ARGs in river water samples all over the world (Pruden et al., 2006; Berendonk et al., 2015) including pristine environment (Pruden et al., 2013; Hsieh et al., 2011; Liyanage \& Manage, 2016a). According to the authors' knowledge, no records are available regarding ARGs (tet $M$, tet $S$, tet $A$, amp a, amp $b$, amp $c$, bla ${ }_{T E M}$, bla $\left.{ }_{\text {OXA }}\right)$ in the Kelani river basin which is the second-largest watershed in Sri Lanka. The river basin covers seven districts, namely, Colombo (446 km², 19\%), Gampaha (343 $\left.\mathrm{km}^{2}, 14.7 \%\right)$, Kaluthara $\left(12 \mathrm{~km}^{2}, 0.5 \%\right)$, Kegalle $\left(1,028 \mathrm{~km}^{2}, 44 \%\right)$, Rathnapura $\left(70 \mathrm{~km}^{2}, 3 \%\right)$, Nuwara Eliya $\left(430 \mathrm{~km}^{2}, 18.4 \%\right)$, and Kandy $\left(4 \mathrm{~km}^{2}\right.$, $0.2 \%$ ). However, since the river flows through the urban centers, farmlands, and industrial zones, it is more vulnerable to water pollution (Mahagamage \& Manage, 2014; Mahagamage et al., 2016) and it is the most polluted river in Sri Lanka due to the rapid growth of industries located in close vicinity of the river and passes through the most populated capital city of the country (Mahagamage et al., 2014; CEA, 2015). Thus, the present study is the first report on the screening of the potential of ARGs with special emphasis on penicillin and tetracycline in surface and groundwater samples collected from the meandering zone of the Kelani river basin, Sri Lanka. 
The penicillin resistance genes (bla ${ }_{T E M}$, bla ${ }_{O X A}$, OPR D, amp a, amp $b$ ) were detected in a high percentage (5-30\%) comparable to the resistance genes recorded for tetracycline (tet $A$, tet $M$, tet $S$, tet $B$ ) in surface water. Similarly, a high number of locations were positive for penicillin resistance genes (5-15\%) compared to the resistance genes of tet A, tet $M$, tet $B$, and tet $S$ belonging to the group tetracycline (OTC and TET) $(\sim 10 \%)$ in groundwater. Thus, results were suggesting usage of specific antibiotics in particular aspects causes ARGs development in the environment.

The results of the study clearly showed that ARGs are present in various environmental compartments. Moreover, the presence of antibiotics in a sub-inhibitory concentration may induce horizontal gene transfer within bacterial communities (Shah et al., 2008), which further increases the prevalence of ARGs.

In this study, a potent rapid molecular technique, real-time PCR, was applied to quantify the concentrations of ARGs (tet $M$, tet A, amp a, OPR D, bla TEM) in ground and surface water samples. The method proved to be very efficient, reproducible, and sensitive for the quantification of selected resistance genes in water samples with high efficiency values (96.84-107.71\%).

Likewise, Mao et al., (2015) suggested that water in river water and river mouth is a significant point source of several ARGs into the receiving environment. In the case of penicillin and tetracycline resistance genes, concentration in water samples of the Kelani river may become severe due to detection of the respective gene without detection of any selected penicillin (AMX, ampicillin, cloxacillin) or tetracycline (TET, OTC) in water samples. Thus, it will be confirmed that the spreading of ARGs and ARB was not totally dependent on antibiotic concentration. Altogether, these observations undoubtedly demonstrate the contribution of effluent water discharges to the spread of antibiotic resistance in the natural environment.

Further, data obtained from the present study was used to analyze the correlation between the absolute concentrations of selected genes vs the antibiotics. However, no significant correlation $(p>0.05)$ was found between antibiotic concentration in the environment and antibiotic resistance genes. Further, it was found that the resistance genes were detected with the absence of tetracycline and penicillin in water. Thus, the results of the study suggest that the increase in the prevalence of resistance genes is caused by the persistence of these genes even the absence of selection pressure (Kim et al., 2012). However, the results presented in this study are consistent with previous studies suggesting that exposure to antibiotics could be the main factor that leads to selective pressure for ARGs (Franje et al., 2010).

The highest EC values were recorded in Mattakkuliya river mouth $(1040 \mu \mathrm{S} / \mathrm{cm})$ and the Hemilton canal $(2330 \mu \mathrm{S} / \mathrm{cm})$ which exceeded the standard given by SLSI for drinking water quality $(750 \mu \mathrm{S} /$ $\mathrm{cm})$. All other water quality parameters remained the SLSI values given for drinking water except microbiological parameters (TC and FC). It was found that all the surface and groundwater samples were contaminated with TC and FC bacteria and exceeded the values given by SLSI for drinking water standards.

Thus, based on the results obtained from the present study and the available literature, the authors suggest that further studies are needed to update which concentrations of antibiotic resistance are developed, disseminated, and variations of that concentration with a different type of environment in the future.

\section{Conclusion}

The present study is the first study on antibiotics and ARGs in the meandering zone of the Kelani river basin in Sri Lanka. The results of the study revealed that surface and groundwater are possible reservoirs of ARGs. Further, pathogen-associated taxonomic groups in the Kelani river had implications for human health is suggested. The study highlighted that the great impact of heavy and unregulated use of antibiotics along with the discharge of partially or untreated wastewater into the aquatic environment might cause significant contamination of both antibiotics and ARGs. Furthermore, development of antibiotic resistance create huge problem in treating bacterial infections in near future. Thus, great concern should be given to the amount of antibiotic resistance in the aquatic environment that can serve as a harbor of resistance for the pathogens as ARGs and ARB may be creating a potential risk to human and animal health. 


\section{References}

Aminov, R. I., \& Mackie, R. I. (2007). Evolution and ecology of antibiotic resistance genes. FEMS Microbiology Letters, 271(2), 147-161.

APHA. (1999). Standard methods for the examination of water and wastewater (20th ed., p. 541). American Public Health Association.

Bennett, P. M. (2008). Plasmid encoded antibiotic resistance: Acquisition and transfer of antibiotic resistance genes in bacteria. British Journal of Pharmacology, 153(S1), S347-S357.

Berendonk, T. U., Manaia, C. M., Merlin, C., Fatta-Kassinos, D., Cytryn, E., Walsh, F., Burgmann, H., Sorum, H., Norstrom, M., Pons, M. N., \& Kreuzinger, N. (2015). Tackling antibiotic resistance: The environmental framework. Nature Reviews Microbiology, 13(5), 310-317.

CDC. (2013). Health with special features. Available at: https://www.cdc.gov/nchs/data/hus/hus09.pdf (Accessed on Nov 2017).

CEA. (2014). Available at: from http://www.cea.lk/web/ index.php/en. Accessed May 2019.

CEA. (2015). Available at: from http://www.cea.lk/web/en/ acts-regulations. Accessed Dec 2019.

CEA. (2017). Available at: from http://www.cea.lk/web/ index.php/en (Accessed on May 2019).

Danish Hydraulic Institute. (1999). Western river basins sector project. Phase 1 Report. Annex 1. River Basin Assessments (June 1999).

Fernandez-Torres, R., Consentino, M. O., Lopez, M. B., \& Mochon, M. C. (2010). Simultaneous determination of 11 antibiotics and their main metabolites from four different groups by reversed-phase high-performance liquid chromatography-diode array-fluorescence (HPLC-DADFLD) in human urine samples. Talanta, 81(3), 871-880.

Franje, C. A., Chang, S. K., Shyu, C. L., Davis, J. L., Lee, Y. W., Lee, R. J., \& Chou, C. C. (2010). Differential heat stability of amphenicols characterized by structural degradation, mass spectrometry and antimicrobial activity. Journal of Pharmaceutical and Biomedical Analysis, 53(4), 869-877.

Hernandes F., Henriques L., Pilz R., Bonifacio O., Boechat Salloto G., Oliveira Santoro D., Mandetta M. \& Machado, A. (2013). Antibiotic resistance in aquatic environments of Rio de Janeiro, Brazil. Perspectives in Water Pollution, [Online]. Available at: http://www.intechopen.com/books/ perspectives-in-water-pollution/antibiotic-resistance-inaquatic-environments-of-rio-de-janeiro-brazil. (Accessed: October 2015)

Hsieh, M. K., Shyu, C. L., Liao, J. W., Franje, C. A., Huang, Y. J., Chang, S. K., \& Chou, C. C. (2011). Correlation analysis of heat stability of veterinary antibiotics by structural degradation, changes in antimicrobial activity and genotoxicity. Vet Med (praha), 56, 274-285.

Huddleston, J. R. (2014). Horizontal gene transfer in the human gastrointestinal tract: Potential spread of antibiotic resistance genes. Infection and Drug Resistance, 7, 167.

Kim S.J., Ogo M., Oh M.J. \& Suzuki S. (2012). Occurrence of tetracycline resistant bacteria and tet $(\mathrm{M})$ gene in seawater from Korean coast. Interdisciplinary studies on environmental chemistry-Environmental pollution and ecotoxicology. TERRAPUB, 367-375.

Laxminarayan R, Bhutta Z, Duse A, Jenkins P, O'Brien T, Okeke I.N, Pablo-Mendez A. \& Klugman K.P. (2013). Drug resistance. In Disease control priorities in developing countries, edited by Jamison DT, Breman JG, Measham AR et al, World Bank, Washington (DC), 1031-1051.

Liyanage G.Y. \& Manage P.M. (2014). Quantification of oxytetracycline and amphicillin in two wastewater discharging points in Colombo, Sri Lanka, Journal of Environemnt and Natural Resources, Thailand. 193-198.

Liyanage G.Y. \& Manage P.M. (2016 a). Occurrence, fate and ecological risk of antibiotics in hospital effluent water and sediments in Sri Lanka, International Journal of Agriculture and Environmental Research, 4. 909-935.

Liyanage G.Y. \& Manage P.M. (2016 b). Occurrence and distribution of tetracycline resistance determinants and their pollution status in the aquaculture environment of Sri lanka. $3^{\text {rd }}$ International Conference on Multidisciplinary Approaches Proceeding, 8.

Liyanage G.Y., Manage P.M. \& De Alwis A. (2015). Study on the occurrence of antibiotic contaminations in the aquatic environment, Sri Lanka. International Conference on Multidisciplinary Approaches Proceeding, 198.

Liyanage, G. Y., \& Manage, P. M. (2018). Degradation of ciprofloxacin (CIP) by bacteria isolated from effluent water and identification of degradation pathways. International Journal of Medical, Pharmacy and Drug Research, 2(3), 37-47.

Mahagamage, M. G. Y. L., \& Manage, P. M. (2014). Water quality index (CCME-WQI) based assessment study of water quality in Kelani river basin, Sri Lanka. The 1st Environment and Natural Resources International Conference (ENRIC 2014). Mahidol University, Thailand, 1, 199-204.

Mahagamage M.G.Y.L. \& Manage, P. M. (2015). Mapping spatial distribution of water quality parameters of groundwater in the Kelani river basin using GIS., 12th International Conference on Environmental Science and Development (ICESD), Singapore p. 10-14.

Mahagamage, M. G. Y. L., \& Manage, P. M. (2018). Socioeconomic background of the head and transitional regions of the Kelani river basin Sri Lanka. Asian Journal of Microbiology, Biotechnology and Environnemental Sciences, 20(3), 43-57.

Mahagamage, M. G. Y. L., \& Manage, P. M. (2019). Water quality and microbial contamination status of Madawachchiya, Padaviya and Kebathigollewa areas in Anuradhapura District, Sri Lanka. Journal of Water and Land Development, 42(3), 1-11. https://doi.org/10.24425/jwld. 2019.127001.

Mahagamage M.G.Y.L., Chinthaka S.D.M., Manage P.M. (2014). Multivariate analysis of physico-chemical and microbial parameters of surface water in Kelani river basin. International Journal of Multidisciplinary Studies (IJMS), 1. (1); 55-61.

Mahagamage, M. G. Y. L., Chinthaka, S. D. M., \& Manage, P. M. (2016). Assessment of water quality index for the groundwater in Kelani river basin, Sri Lanka. 
International Journal of Agriculture and Environmental Research, 5, 1158-1171.

Mahagamage, M. G. Y. L., Pathirage, S., \& Manage, P. M. (2020). Contamination status of Salmonella spp., Shigella spp. and Campylobacter spp. in surface and groundwater of the Kelani river basin Sri Lanka. Water, 12, 2187.

Manage, P. M. (2018). Heavy use of antibiotics in aquaculture: Emerging human and animal health problems-A review. Sri Lanka Journal of Aquatic Science, 23(1), 13-28.

Manage, P. M., \& Liyanage, G. Y. (2019). Antibiotics induced antibacterial resistance. In Pharmaceuticals and personal care products: waste management and treatment technology (pp. 429-444). Elsevier.

Manage, P., Mahagamage, Y. L., Ajward, R., Amaratunge, S., \& Amarathunga, V. I. (2020). The need for proper management leading to the sustainability of the Kelani river and its lower basin. Journal of Water and Land Development, 47(X-XII):10-15.

Mao, W., Vu, H., Xie, Z., Chen, W., \& Tang, S. (2015). Systematic review on irrational use of medicines in China and Vietnam. PloS one, 10(3), e0117710.

Marti, E., Jofre, J., \& Balcazar, J. L. (2013). Prevalence of antibiotic resistance genes and bacterial community composition in a river influenced by a wastewater treatment plant. PLoS One, 8(10), e78906.

Ministry of Health. (2015). Medicine and indigenous medicine. Available at: http://www.health.gov.lk/moh_final/english/ others.php?pid=101. Accessed Oct 2016.

Ministry of Health, Medicine and Indigenous Medicine, Available at: http://www.health.gov.lk/moh_final/english/others.php?pid=101. (Accessed on Oct 2017).

MOFE, (2001). State of the environment—Sri Lanka. Ministry of Forestry and Environment, Battaramulla, Sri Lanka.

NAQDA, (2015). Available at: http://www.fao.org/3/a-bp876e. pdf. http://www.naqda.gov.lk/our-centers/coastal-aquac ulture-development-centers/. (Accessed on Nov 2017).

Perini, F., Casabianca, A., Battocchi, C., Accoroni, S., Totti, C., \& Penna, A. (2011). New approach using the real-time PCR method for estimation of the toxic marine dinoflagellate Ostreopsis cf ovata in marine environment. PLoS One, 6(3), e17699.

Pruden, A., Larsson D. J., Amézquita A., Collignon P., Brandt K. K., Graham D. W. \& Topp E. (2013). Management options for reducing the release of antibiotics and antibiotic resistance genes to the environment. Environmental Health Perspectives (Online), 12.1(8); 878.

Pruden, A., Pei, R., Storteboom, H., \& Carlson, K. H. (2006). Antibiotic resistance genes as emerging contaminants: Studies in northern Colorado. Environmental Science \& Technology, 40(23), 7445-7450.

Qadir, A., Malik, R. N., \& Husain, S. Z. (2008). Spatio-temporal variations in water quality of Nullah Aik-tributary of the river Chenab Pakistan. Environ Monit Assess, 140, 43-59.

Roberts, C. M. (2005). Update on acquired tetracycline resistance gene. FEMS Microbiology Letters, 245, 195-203.

Russell A.D. (2004). Types of antibiotics and synthetic antimicrobial agents. Hugo and Russell's, 152.

Shah, A. A., Hasan, F., Hameed, A., \& Ahmed, S. (2008). Biological degradation of plastics: A comprehensive review. Biotechnology Advances, 26(3), 246-265.

SLSCI 2013. Microbiological test methods for water. Part 1 -Detection and enumeration of Escherichia coli and Coliform bacteria-Section 2-Reference method, SLS 1461 Part 1 Section 3. Colombo. Sri Lanka Standards Institution.

Stikker, A. (1998). Water today and tomorrow. Futures, 30, 43-62.

WHO (2009) World health statistics, Available at: http://www. who.int/whosis /who stat/EN_WHS2011_Full.pdf?ua=1. (Accessed on December 2017).

World Health Organization (2018). Global action plan on antimicrobial resistance. p.Geneva: World Health Organization. Available at: http://www.who.int/drugresistance/ global_action_plan/en/. (Accessed on Dec 2018).

Zhang, T., \& Li, B. (2011). Occurrence, transformation, and the fate of antibiotics in municipal wastewater treatment plants. Critical Reviews in Environmental Science and Technology, 41(11), 951-998.

Publisher's Note Springer Nature remains neutral with regard to jurisdictional claims in published maps and institutional affiliations. 